\title{
Therapeutic effect of a novel histone deacetylase 6 inhibitor, CKD-L, on collagen- induced arthritis in vivo and regulatory $T$ cells in rheumatoid arthritis in vitro
}

Bo Ram Oh', Dong-hyeon Suh², Daekwon Bae², Nina Ha², Young II Choi ${ }^{2}$, Hyun Jung Yoo ${ }^{3}$, Jin Kyun Park ${ }^{3}$, Eun Young Lee ${ }^{3}$, Eun Bong Lee ${ }^{3}$ and Yeong Wook Song ${ }^{1,3^{*}}$

\begin{abstract}
Background: Histone deacetylase (HDAC) inhibitor has recently been reported to have a therapeutic effect as an anti-inflammatory agent in collagen-induced arthritis (CIA). We investigated the therapeutic effect of a new selective HDAC6 inhibitor, CKD-L, compared to ITF 2357 or Tubastatin A on CIA and regulatory T (Treg) cells in patients with rheumatoid arthritis (RA).

Methods: CIA was induced by bovine type II collagen (CII) in DBA/1 J mice. Mice were treated with HDAC inhibitor for 18 days. Arthritis score was assessed and histological analysis was performed by hematoxylin and eosin (H\&E) stain. Cytotoxic T-lymphocyte associated protein (CTLA)-4 expression in induced Treg cells was analyzed and suppression assay was analyzed using Treg cells and effector T (Teff) cells isolated from naive C57BL/6 mice by flow cytometry. Cytokines were analyzed in peripheral blood mononuclear cells (PBMC) of five patients with RA by enzyme-linked immunosorbent assay (ELISA) and real-time polymerase chain reaction (PCR). Tumor necrosis factor (TNF) was analyzed using PMA- activated THP-1 cells by ELISA. Suppression assay was analyzed using Treg cells and Teff cells isolated from RA patients by flow cytometry.
\end{abstract}

Results: In the CIA model, CKD-L and Tubastatin A significantly decreased the arthritis score. CKD-L increased CTLA-4 expression in Foxp3 ${ }^{+} T$ cells and inhibited the proliferation of Teff cells in the suppression assay. In RA PBMC, CKD-L significantly inhibited TNF and interleukin (IL)-1 $\beta$, and increased IL-10. CKD-L and Tubastatin A inhibited TNF secretion from PMA-activated THP-1 cells. CKD-L and ITF 2357 inhibited the proliferation of Teff cells in RA patients in the suppression assay. Tubastatin A had no effect on inhibition of proliferation.

Conclusion: CKD-L decreased the arthritis score in CIA, reduced the expression of TNF and IL-1 $\beta$, and increased the expression of IL-10 in PBMC from RA patients. CKD-L increased CTLA-4 expression and the suppressive function of Treg cells. These results suggest that CKD-L may have a beneficial effect in the treatment of RA.

Keywords: Histone deacetylase 6, Histone deacetylase inhibitor, Rheumatoid arthritis, Collagen-induced arthritis, Regulatory $T$ cell

\footnotetext{
* Correspondence: ysong@snu.ac.kr

'Department of Molecular Medicine and Biopharmaceutical Sciences, BK 21 plus Graduate School of Convergence Science and Technology, College of Medicine, Seoul National University, Seoul, Korea

${ }^{3}$ Division of Rheumatology, Department of Internal Medicine, Seoul National University College of Medicine, Seoul, Korea

Full list of author information is available at the end of the article
} 


\section{Background}

Histone deacetylase (HDAC) and histone acetyltransferase (HAT) play important roles in the regulation of gene transcription [1]. The positively charged lysine in the $\mathrm{N}$-terminal tail of histones is neutralized by acetylation of histone by HAT, and the binding affinity between the DNA backbone and histones is decreased because histones do not bind to the negatively charged phosphate groups in DNA. The decreased level of interaction between DNA and histones increases gene transcription by promoting the binding of transcription factors to DNA [2-4].

In opposition to HAT, deacetylation of histone by HDAC represses gene transcription through chromatin condensation [5]. HDAC is classified into four classes based on DNA sequence similarity and function. Class I, II, and IV HDACs are classical HDACs that have a zincdependent active site, whereas class III HDACs are a family of nicotinamide adenine dinucleotide $\left(\mathrm{NAD}^{+}\right)$-dependent proteins. Class I HDACs (HDACs $1-3$ and 8 ) are primarily found in the nucleus, and class II HDACs (HDAC 4-7, 9, and 10) are found in both the nucleus and the cytoplasm and can shuttle between the two. The class IV HDAC (HDAC11) shares structural similarities with both class I and class II HDACs. Class III HDACs (SirT 1-7) have distinct structures and different mechanisms of action. Their enzymatic activity depends on the cofactor $\mathrm{NAD}^{+}[1,6,7]$.

HDAC6 is primarily located in the cytoplasm and has a unique structure that contains two homologous catalytic domains and an ubiquitin binding domain at the $\mathrm{C}$ terminal end $[8,9]$. HDAC6 has been reported to involve many important biological processes, including cell migration, immune response, viral infection, and the degradation of misfolded proteins. The substrates of HDAC6 are $\alpha$-tubulin, heat shock protein (HSP) 90, peroxiredoxin (PRX), and cortactin, and HDAC6 regulates acetylation of multiple proteins by forming various complexes with other partner proteins. These diverse functions of HDAC6 offer potential therapeutic targets in various diseases such as systemic lupus erythematosus, cancer, and diabetes $[10,11]$. The inhibition of HDAC6 was reported to enhance the suppressive activity of regulatory $\mathrm{T}$ cells (Treg cells) in inflammation and autoimmunity [12].

Histone deacetylase inhibitors modulate the function of HDACs and activate and/or repress gene expression. HDAC inhibition leads to cell cycle arrest, cell growth, cell differentiation, and apoptotic death of transformed cells $[13,14]$. HDAC inhibitors have been developed; the pan HDAC inhibitors, such as ITF 2357 and SAHA, inhibit all HDACs, and the selective HDAC inhibitors, such as Tubastatin A and Tubacin, inhibit HDAC6 specifically [15].
Epigenetic regulation plays an important role in inflammatory autoimmune diseases including rheumatoid arthritis (RA) through changes in histone modification [16]. RA is a chronic autoimmune disease characterized by inflammatory synovitis and progressive destruction of joint cartilage and bone, leading to swelling, pain, stiffness, and loss of function $[17,18]$. The etiology of RA remains unclear, but genetic background and environmental factors play important roles in the disease [19].

Current medical treatments for RA include nonsteroidal anti-inflammatory drugs (NSAIDs) and diseasemodifying antirheumatic drugs (DMARDs), including methotrexate (MTX), sulfasalazine, and tumor necrosis factor (TNF) inhibitors (infliximab, etanercept, and adalimumab) [20]. TNF is a proinflammatory cytokine that is associated with the development of RA. TNF blockade can be an effective treatment for RA [21]. However, about $40 \%$ of RA patients do not respond to antiTNF therapy, so novel therapies are required for patients who show no response $[1,5]$.

HDAC inhibitors have been reported to have potential therapeutic effects as anti-inflammatory agents in many studies including those on collagen-induced arthritis (CIA) [5, 22-25]. HDAC inhibitors suppressed the production of interleukin (IL)-6 in RA fibroblast-like synoviocytes (FLS) and macrophages by promoting mRNA decay [26]. In RA, macrophages and $\mathrm{T}$ cells are major sources of proinflammatory cytokines [27]. The activation, survival, and apoptosis of macrophages are regulated by acetylation and deacetylation of histones. HDAC inhibitors suppress TNF and IL-6 production and cytokine gene transcription and induce apoptosis in macrophages [28]. HDAC inhibitors reduce the secretion of proinflammatory cytokines, such as TNF and IL-6, in peripheral blood mononuclear cells (PBMC) of RA patients and reduce the secretion of TNF, IL- $1 \alpha$, IL-1 $\beta$, and interferon (IFN)- $\gamma$ in lipopolysaccharide (LPS)-stimulated normal PBMC [1, 24]. Treg cells are a subset of $\mathrm{CD}^{+}{ }^{+} \mathrm{T}$ cells that have an immunosuppressive role in immune tolerance [29]. Treg cells from RA patients are defective in suppressing proinflammatory cytokine production [30].

Tubastatin A inhibited HDAC6 and induced Foxp3 expression, resulting in enhanced Treg function [12]. In addition, Tubastatin A suppressed TNF and IL-6 from the THP1 macrophage cell line and inhibited CIA [31]. However, it is still unclear whether HDAC6-selective inhibitors have a similar immunoregulatory function in RA patients.

Here, we introduce a new HDAC6 selective inhibitor, CKD-L, developed by the Chong Kun Dang Pharmaceutical Corporation. Although the tertiary amine tricycle of Tubastatin A has excellent HDAC6-selective inhibitory activity, the poor PK profile and genotoxicity of 
Tubastatin A significantly limited its development for clinical use. CKD-L has a bicycle instead of a tertiary amine tricycle, resulting in better drug-like structure and profiles without any genotoxicity in the Ames test and the chromosome aberration test.

We investigated the therapeutic effect of the novel selective HDAC6 inhibitor, CKD-L, and compared its effect to those of the pan HDAC inhibitor, ITF 2357, and the selective HDAC6 inhibitor, Tubastatin A, in CIA, PBMC, and Treg cells from patients with RA. CKD-L showed comparable efficacy to Tubastatin A in the CIA model. Moreover, CKD-L showed immunomodulatory effect in RA patients, such as improvement of Treg function and suppression of TNF production in PBMC suggesting that HDAC6 may be an important therapeutic target protein to control RA, and that HDAC6specific inhibitors such as CKD-L can be developed for clinical use.

\section{Methods}

\section{Chemicals}

CKD-L is a new histone deacetylase 6 inhibitor developed by the Chong Kun Dang Pharmaceutical Corporation (CKD Pharm). ITF 2357 and Tubastatin A were also provided by CKD Pharm and were used as positive controls (pan HDAC inhibitor and selective HDAC6 inhibitor, respectively). These chemicals were dissolved in dimethyl sulfoxide (DMSO; Sigma-Aldrich, St. Louis, MO, USA). The stock solutions were stored at $-20{ }^{\circ} \mathrm{C}$ and were diluted to the required concentrations in growth media as necessary. Vehicle (DMSO) was used in the negative control groups.

\section{Animals}

DBA/1 J mice (male, 6 weeks old) and C57BL/6 mice (male, 6 weeks old) were purchased from Central Lab Animal, Inc. (SLP, Hamamatsu, Japan). The animals were kept in a specific pathogen-free facility. The animals were provided with standard diet and water ad libitum. The animal study was reviewed and approved by the CKD Institutional Animal Care and Use Committee (approval number: S-16-038).

\section{$\mathrm{CIA}$ experiments}

Before the first immunization, bovine type II collagen (CII; Chondrex, Redmond, WA, USA) $2 \mathrm{mg} / \mathrm{ml}$ in $0.05 \mathrm{M}$ acetic acid and an equal volume of complete Freund's adjuvant (CFA; Chondrex) were mixed by using a precooled homogenizer in an ice bath; $100 \mu \mathrm{l}$ of the emulsion was injected intradermally at the base of the tail of each DBA1/J mouse on day 1.

On day 21 after the first immunization, the mice were boosted with the second immunization. Bovine type II collagen $(2 \mathrm{mg} / \mathrm{ml}$ in $0.05 \mathrm{M}$ acetic acid) and an equal volume of incomplete Freund's adjuvant (IFA; Chondrex) were mixed by using a precooled homogenizer in an ice bath; $100 \mu \mathrm{l}$ of the emulsion was injected intradermally at the base of the tail of each mouse.

\section{Drug administration and evaluation of arthritis}

After the second immunization, the mice were divided into four equal groups on the basis of their body weight and given either vehicle or HDAC6 inhibitors. CKD-L and Tubastatin A were dissolved in cremophor EL:ethanol:saline (1.5:1.5:7). Mice were treated with vehicle $(n=10)$, CKD-L (15 or $30 \mathrm{mg} / \mathrm{kg}, n=10$ for both), or Tubastatin A (30 $\mathrm{mg} / \mathrm{kg}, n=9$ ) by subcutaneous injection every day for 18 days. Arthritis score and body weight were assessed every 2 days after the first drug administration. On day 38, all mice were sacrificed after anesthetization for pathological analysis.

\section{Arthritis score assessment}

Arthritis score was evaluated as 5 scales as previously reported [32]: $0=$ no evidence of erythema and swelling; $1=$ erythema and mild swelling confined to the tarsals or ankle joint; $2=$ erythema and mild swelling extending from the ankle to the tarsals; $3=$ erythema and moderate swelling extending from the ankle to metatarsal joints; $4=$ erythema and severe swelling encompass the ankle, foot and digits, or ankylosis of the limb.

Arthritis was scored using a scale of $0-4$ for each paw. The total score per mouse was summed from 0 to 16 $($ normal $=0$; maximum severe score $=16$ ).

\section{Body weight change after onset of arthritis}

Change in body weight (\%) is a general marker of various diseases including RA. Thus, body weight change after the onset of arthritis can reflect disease progression.

\section{Histological score}

The knee joints and hind paws of mice in each group were dissected for histopathological analysis. Dissected knee joints and hind paws were fixed in 10\% phosphatebuffered formalin ( $\mathrm{pH}$ 7.4), decalcified in $10 \%$ ethylenediaminetetraacetic acid (EDTA) for approximately 2 weeks, embedded in paraffin, and then processed as per standard methods. The sections were stained with hematoxylin and eosin (H\&E) and scored by seven independent, blinded observers. Synovial inflammation, bone erosion, cartilage damage, and leukocyte infiltration were assessed using a scale of $0-4$ (normal $=0$; mild $=1$; $\bmod$ erate $=2$; marked $=3$; severe $=4$ ). Histological score was calculated by summation of these scales (normal $=0$; maximum score $=16$ ). 
CTLA-4 expression using induced murine Treg cells Cell preparation and enzymatic digestion

Spleens from naive C57BL/6 mice were harvested and then incubated with $2 \mathrm{mg} / \mathrm{ml}$ collagenase D (Roche, Mannheim, Germany) for $30 \mathrm{~min}$ at $37{ }^{\circ} \mathrm{C}$. Spleens were meshed through a $70-\mu \mathrm{m}$ cell strainer (Becton Dickinson, Franklin Lakes, NJ, USA) to obtain single cell suspensions.

Treg cells $\left(\mathrm{CD} 4^{+} \mathrm{CD} 25^{+} \mathrm{T}\right.$ cells) and effector $\mathrm{T}$ (Teff) cells $\left(\mathrm{CD} 4^{+} \mathrm{CD} 25^{-} \mathrm{T}\right.$ cells) were isolated from splenocytes using a $\mathrm{CD} 4^{+} \mathrm{CD} 25^{+}$regulatory $\mathrm{T}$ Cell Isolation Kit (Miltenyi Biotec, Bergisch-Gladbach, Germany) by magnetic cell sorting (MACS) separator according to the manufacturer's instructions. The purity of each cell population $(>95 \%)$ was confirmed by flow cytometry.

\section{Treg cell induction and drug treatment}

$\mathrm{CD} 4{ }^{+} \mathrm{CD} 25^{-} \mathrm{T}$ cells were isolated from splenocytes using the $\mathrm{CD} 4{ }^{+} \mathrm{CD} 25^{+}$regulatory $\mathrm{T}$ Cell Isolation Kit (Miltenyi Biotec) as a negative fraction by MACS separator. The purity of the isolated cell population (>95\%) was confirmed by flow cytometry.

$\mathrm{CD} 4^{+} \mathrm{CD} 25^{-} \mathrm{T}$ cells $\left(5 \times 10^{5}\right.$ cells $/ \mathrm{ml} /$ well $)$ were incubated with vehicle or HDAC6 inhibitor (1 to $10 \mu \mathrm{M})$ in the presence of antiCD3/CD28 beads (T cell Activation/ Expansion kit, Miltenyi Biotec), and recombinant mouse transforming growth factor (TGF)- $\beta 2(40 \mathrm{pg} / \mathrm{ml} ; \mathrm{R} \& \mathrm{D}$ systems Inc., Minneapolis, MN, USA) in a 48-well plate (Becton Dickinson) for 6 days at $37{ }^{\circ} \mathrm{C}$ in a humidified $5 \% \mathrm{CO}_{2}$ incubator.

For surface staining, cells were incubated with PE-Cy7labeled antimouse CD4 (eBioscience), and APC-labeled antimouse CD25 (eBioscience) for $20 \mathrm{~min}$ at room temperature (RT). For intracellular staining, the cells were fixed and permeabilized with fix/permeabilization buffer (eBioscience) for $20 \mathrm{~min}$ at $4{ }^{\circ} \mathrm{C}$, washed twice with wash buffer, and then incubated with AlexaFluor488-labeled antimouse forkhead box P3 (Foxp3) and PE-labeled antimouse CTLA-4 (eBioscience) for $20 \mathrm{~min}$ at $4{ }^{\circ} \mathrm{C}$ in the dark. CTLA-4 expression of induced Foxp $3^{+}$Treg cells was analyzed by FACS CantoII flow cytometry (BD bioscience, San Jose, CA, USA) and the results were analyzed with FlowJo software (TreeStar Inc. Ashland, OR, USA).

\section{Suppression assay using murine natural Treg cells and Teff cells \\ Isolation of Treg cells and Teff cells}

Treg cells and Teff cells were isolated from splenocytes of naive C57BL/6 using $\mathrm{CD} 4{ }^{+} \mathrm{CD} 25^{+}$regulatory $\mathrm{T}$ Cell Isolation Kit (Miltenyi Biotec) by MACS separator according to the manufacturer's instructions. The purity of each cell population was $>95 \%$ as confirmed by flow cytometry.

\section{Labeling of Teff cells}

Teff cells were labeled with $5 \mathrm{uM}$ Cell Proliferation Dye efluor ${ }^{\circ} 670$ (eBioscience) for $10 \mathrm{~min}$ at $37{ }^{\circ} \mathrm{C}$ under protection from light.

\section{Suppression assay}

Treg cells were mixed with eFluor 670 -labeled Teff cells at ratios of 4:1 and 0:1 in RPMI1640 media (Gibco, MA, USA) containing 10\% heat-inactivated fetal bovine serum (FBS; Gibco), 1\% penicillin/streptomycin (P/S; Gibco), $1 \mathrm{mM}$ sodium pyruvate (Gibco), and 1\% 2-mercaptoethanol (Gibco) in a 96-well round bottom plate (Becton Dickinson). The mixed cells were incubated with vehicle (DMSO final concentration $0.1 \%$ ) or HDAC6 inhibitor (1 to $10 \mathrm{uM}$ ) in the presence of antiCD3/CD28 beads ( $\mathrm{T}$ cell Activation/ Expansion kit, Miltenyi Biotec) for 4 days. Proliferation of Teff cells was analyzed using FACS LSR Fortessa (BD bioscience). The results were analyzed by FlowJo software (TreeStar Inc.).

\section{RA patients}

\section{RA patients and healthy controls}

Patients with RA were enrolled at the Rheumatology Clinic, Seoul National University Hospital. All RA patients fulfilled the 1987 American College of Rheumatology (ACR) classification criteria of RA [33]. Healthy controls were volunteers who did not have RA. This study was approved by the Institutional Review Board (IRB No.: 1207-153-421) and informed consent was obtained from each patient.

\section{Methylthiazol tetrazolium (MTT) assay and cell viability}

Heparinized blood of RA patients was diluted with an equal volume of phosphate-buffered saline (PBS), and diluted whole blood was carefully layered over FicollPaque $^{\mathrm{Tm}}$ PLUS (specific gravity $1.007 \mathrm{~g} / \mathrm{ml}$; GE Healthcare Life Science, Uppsala, Sweden) (blood:PBS:Ficoll = 1:1:1). After centrifugation at $1700 \mathrm{rpm}$ for $30 \mathrm{~min}$ at RT, PBMC were isolated from the plasma and Ficoll interface and washed twice with PBS.

Isolated PBMC were cultured in a 96-well plate and treated with LPS (100 ng/ml; Sigma-Aldrich) and vehicle or HDAC inhibitor $(0.01$ to $5 \mu \mathrm{M})$ in RPMI 1640 media containing $10 \%(\mathrm{v} / \mathrm{v})$ FBS and $1 \% \mathrm{P} / \mathrm{S}(10,000$ units $/ \mathrm{ml}$; Gibco/BRL, Grand Island, NY, USA) for $24 \mathrm{~h}$ at $37^{\circ} \mathrm{C}$ in a humidified $5 \% \mathrm{CO}_{2}$ incubator. For the MTT assay, $10 \mu \mathrm{l}$ CCK-8 solution (CCK-8; Dojindo Laboratory, Kumamoto, Japan) was added to each well and incubated for $2 \mathrm{~h}$ at $37{ }^{\circ} \mathrm{C}$ in the dark. The absorbance in solution was measured by a Luminex 200 (Luminex Corporation, Austin, TX, USA) at $450 \mathrm{~nm}$. 


\section{Cytokine assay}

Isolated PBMC were cultured in a 48-well plate (Becton Dickinson) and treated with LPS (100 ng/ml) and vehicle or HDAC inhibitor (0.01 to $5 \mu \mathrm{M}$ ) in RPMI 1640 media containing $10 \% \mathrm{FBS}$ and $1 \% \mathrm{P} / \mathrm{S}$ for $24 \mathrm{~h}$ at $37{ }^{\circ} \mathrm{C}$ in a humidified $5 \% \mathrm{CO}_{2}$ incubator. Cell culture supernatant was harvested for multiplex immunoassay of TNF, IL-1 $\beta$, and IL-10 using Bio-Plex Pro ${ }^{\mathrm{Tm}}$ Assay (Bio-Rad Laboratories, Hercules, CA, USA) according to the manufacturer's instructions. The secretion of IL- 6 in the cell culture supernatant was measured by using the Human IL-6 DuoSet enzyme-linked immunosorbent assay (ELISA) kit (R\&D) according to the manufacturer's instructions.

\section{RNA preparation}

Cells were harvested and washed with PBS for RNA preparation. Total RNA was extracted using an RNeasy micro kit (Qiagen, Valencia, CA, USA) according to the manufacturer's instructions. In brief, $350 \mu$ RLT buffer was added to the pelleted cells $\left(5 \times 10^{5}\right.$ cells $)$ to lyse them. An equal volume of $70 \%$ ethanol was added to the lysate and gently mixed by pipetting. The mixed lysate was transferred into an RNeasy MinElute spin column placed in a $2 \mathrm{ml}$ collection tube and centrifuged at $8000 \mathrm{~g}$ for $15 \mathrm{~s}$ at RT. After washing with $350 \mu \mathrm{l}$ RW1 buffer, $80 \mu \mathrm{l}$ DNase I working solution was added directly to the column membrane and incubated for $15 \mathrm{~min}$ at RT. After washing with $350 \mu \mathrm{l}$ RW1 buffer, $500 \mu \mathrm{l}$ RPE buffer was added to the column, which was centrifuged at $8000 \mathrm{~g}$ for $15 \mathrm{~s}$ at RT. Then $500 \mu \mathrm{l} 80 \%$ ethanol was added to the column and centrifuged at $8000 \mathrm{~g}$ for $2 \mathrm{~min}$ at RT. The column was transferred in a new $1.5-\mathrm{ml}$ collection tube and $14 \mu \mathrm{l}$ RNase-free water was directly added to the center of the column membrane. The column was centrifuged at full speed for $1 \mathrm{~min}$ at RT to elute the RNA. The concentration of RNA was determined by measuring absorbance at $260 \mathrm{~nm}$ with a Nanodrop ND-100 spectrometer (Nanodrop Technologies, Wilmington, DE, USA).

\section{Reverse transcription-polymerase chain reaction (RT-PCR) and complementary DNA (CDNA) synthesis}

First-strand cDNA was synthesized from an equal concentration of total RNA by using the SuperScript ${ }^{\circ}$ III First-Strand Synthesis System (Invitrogen, Carlsbad, CA, USA). The reaction was conducted in a final volume of $10 \mu \mathrm{l}$ containing $20 \mathrm{ng}$ total RNA, $5 \mu \mathrm{M}$ oligo $(\mathrm{dT})_{20}$ primer, and $1 \mathrm{mM}$ deoxynucleotide triphosphate (dNTP) mixture in a 200- $\mu$ l tube. The tube was incubated for $5 \mathrm{~min}$ at $65{ }^{\circ} \mathrm{C}$ and placed on ice for at least $1 \mathrm{~min}$. A cDNA synthesis mix solution was prepared with $10 \times \mathrm{RT}$ buffer, $10 \mathrm{mM}$ DTT, $50 \mathrm{mM} \mathrm{MgCl} 2,2$ units of RNaseOUT, and 10 units of SuperScript ${ }^{\circ}$ III RT. Then $10 \mu \mathrm{l}$ of that mix solution was added to each reaction mixture, mixed gently, and incubated for $50 \mathrm{~min}$ at $50{ }^{\circ} \mathrm{C}$ and for $5 \mathrm{~min}$ at $85^{\circ} \mathrm{C}$, and then placed on ice. To remove the remaining RNA, $1 \mu \mathrm{l}$ RNase $\mathrm{H}$ was added to each reaction mixture for $20 \mathrm{~min}$ at $37{ }^{\circ} \mathrm{C}$ before RT-PCR was performed with a PTC 200 thermal cycler (MJ research Inc., Waltham, MA, USA).

\section{cDNA pre-amplification}

cDNA was amplified using a Taqman PreAmp Master Mix (Applied Biosystems, Foster City, CA, USA) according to the manufacturer's instructions. In brief, $10 \mu \mathrm{l}$ $20 \times$ Taqman gene expression assay was added to a tube and Tris-EDTA buffer was added to $1 \mathrm{ml}$ total volume. The reaction was performed in a final volume of $50 \mu \mathrm{l}$ containing $12.5 \mu \mathrm{l}$ synthesized cDNA, $5 \mu \mathrm{l} 2 \times$ Taqman preamp master mix, $12.5 \mu \mathrm{l} 0.2 \times$ pooled assay mix, and $20 \mu \mathrm{l}$ nuclease-free water. The reactions were incubated for $10 \mathrm{~min}$ at $95{ }^{\circ} \mathrm{C}$ for one cycle, and then for $15 \mathrm{~s}$ at $95{ }^{\circ} \mathrm{C}$ and $4 \mathrm{~min}$ at $65{ }^{\circ} \mathrm{C}$ for 10 cycles. The amplified products were used after being diluted with Tris-EDTA buffer at a ratio of 1:5 before real-time PCR.

\section{Quantitative real-time $P C R$}

Quantitative real-time PCR was performed by running a Taqman probe in an ABI 7500 real-time PCR system (Applied Biosystems, Foster Ctiy, CA, USA) according to the manufacturer's instructions. Human IL-10 (Hs00961622), TNF (Hs01113624), and 18S (Hs99999901)-specific probes were purchased from Applied Biosystems.

The reaction was performed in a final volume of $20 \mu \mathrm{l}$ containing $5 \mu \mathrm{l}$ diluted amplified cDNA, $1 \mu \mathrm{l} 20 \times$ Taqman gene expression assay buffer, $10 \mu \mathrm{l} 2 \times$ Taqman gene expression master mix, and $4 \mu \mathrm{l}$ nuclease-free water. The reactions were incubated for $15 \mathrm{~min}$ at $94{ }^{\circ} \mathrm{C}$ for one cycle and then at $94{ }^{\circ} \mathrm{C}(15 \mathrm{~s}), 59{ }^{\circ} \mathrm{C}(30 \mathrm{~s})$, and $72{ }^{\circ} \mathrm{C}(30 \mathrm{~s})$ for 40 cycles. The quantity of target gene was calculated by the difference between the target gene and reference gene in the threshold cycle $(\mathrm{Ct})$. Relative gene expression was determined using the $2^{-\Delta \Delta \mathrm{Ct}}$ method by normalizing with $18 \mathrm{~S}$ as a reference gene.

\section{TNF secretion in phorbol 12-myristate 13-acetate (PMA)-activated THP-1 cell}

THP-1 cell is a human monocytic cell line, and PMAactivated THP-1 releases the inflammatory cytokine TNF. THP- 1 cells were cultured in a 24-well plate $\left(1 \times 10^{5}\right.$ cells/ well) and activated with PMA (10 ng/ml; Sigma-Aldrich) in RPMI 1640 media containing 10\% FBS and 1\% P/S for $24 \mathrm{~h}$ to induce macrophage differentiation. Cells were washed with PBS, treated with vehicle or HDAC inhibitor $(0.1$ to $10 \mu \mathrm{M})$ for $24 \mathrm{~h}$, and then treated with $100 \mathrm{ng} / \mathrm{ml}$ LPS for $4 \mathrm{~h}$ in a humidified $5 \% \mathrm{CO}_{2}$ incubator. The cell 
culture supernatant was harvested and TNF secretion was measured using a TNF ELISA kit (eBioscience) according to the manufacturer's instructions.

\section{Induction of Treg cells from PBMC of RA patients Isolation of $\mathrm{CD} 4^{+} \mathrm{CD} 25^{-} \mathrm{T}$ cells}

$\mathrm{CD} 4^{+} \mathrm{CD} 25^{-} \mathrm{T}$ cells were isolated from PBMC of RA patients by MACS separator according to the manufacturer's instructions. In brief, PBMC were incubated with a cocktail of biotin-conjugated monoclonal antihuman antibodies: CD8, CD14, CD15, CD16, CD19, CD36, CD56, CD123, TCR $\gamma / \delta$, and CD235a (Glycophorin A) in MACS buffer (PBS, $0.5 \%$ bovine serum albumin (BSA), and 2 mM EDTA; pH 7.2) for 10 min at $4{ }^{\circ} \mathrm{C}$ in the dark. Then, cells were incubated with antibiotin microbead for $15 \mathrm{~min}$ at $4{ }^{\circ} \mathrm{C}$. Non-CD $4^{+}$cells were indirectly magnetically labeled using a cocktail of biotin-conjugated antibodies as primary reagent and antibiotin monoclonal antibodies conjugated to microbead as secondary reagent. The labeled cells were removed as a negative fraction using an LD column. Isolated $\mathrm{CD}^{+}$cells were incubated with microbead conjugated to a monoclonal antihuman CD25 antibody (MACS ${ }^{\circ}$ Miltenyi Biotec) for $15 \mathrm{~min}$ at $4{ }^{\circ} \mathrm{C}$. The labeled cells were removed as a negative fraction using an LD column. The purity of isolated $\mathrm{CD} 4{ }^{+} \mathrm{CD} 25^{-} \mathrm{T}$ cells was $>95 \%$ as confirmed by flow cytometry.

\section{Induction of Treg cells}

Antihuman CD3 antibody (eBioscience; $200 \mu \mathrm{l} ; 2 \mu \mathrm{g} / \mathrm{ml}$ PBS) was added to each well of a 48-well plate. After being sealed, the plate was incubated overnight at $4{ }^{\circ} \mathrm{C}$. The coated plate was washed twice with PBS before seeding. CD $4^{+} \mathrm{CD} 25^{-} \mathrm{T}$ cells were cultured with $2 \mu \mathrm{g} / \mathrm{ml}$ antihuman CD28 antibody (BD Pharmingen, San Diego, CA, USA), $2 \mathrm{ng} / \mathrm{ml} \mathrm{IL-2} \mathrm{(Peprotech,} \mathrm{London,} \mathrm{UK),} 5 \mathrm{ng} / \mathrm{ml}$ TGF- $\beta$ (Peprotech, London, UK), and $20 \mathrm{nM} \mathrm{1,25-dihy-}$ droxyvitamin $\mathrm{D}_{3}$ (Sigma-Aldrich) in $\mathrm{X}-\mathrm{VIVO}^{\mathrm{ma}} 15$ media (Lonza, Walkersville, MD, USA) containing $1 \% \mathrm{P} / \mathrm{S}$ and $10 \%$ heat-inactivated human serum $\mathrm{AB}$ (Lonza) for 5 days at $37{ }^{\circ} \mathrm{C}$ in a $5 \% \mathrm{CO}_{2}$ incubator. Induced Treg cells were harvested and washed with PBS. Cells were cultured in X$\mathrm{VIVO}^{\text {ma }} 15$ media containing $20 \mathrm{ng} / \mathrm{ml} \mathrm{IL-2}$ in a new 48well plate for 2 days. The phenotype of induced Treg cells was confirmed by flow cytometry using PerCP-labeled antihuman CD4 antibody, PE-labeled antihuman CD25 antibody, APC-labeled antihuman Foxp3 antibody, and PE-Cy5-labeled antihuman CTLA-4 antibody.

\section{Suppression assay}

Teff cells $\left(\mathrm{CD} 4^{+} \mathrm{CD} 25^{-} \mathrm{T}\right.$ cells $)$ were isolated from PBMC of heathy volunteers by MACS separator and labeled with a CellTrace ${ }^{\mathrm{ma}}$ carboxyfluorescein succinimidyl ester (CFSE) cell proliferation kit (Celltrace, Molecular
Probes, Invitrogen) according to the manufacturer's instructions. In brief, isolated Teff cells were resuspended in prewarmed PBS containing 0.1\% BSA (Sigma-Aldrich) at a final concentration of $1 \times 10^{6}$ cells $/ \mathrm{ml}$. Teff cells were labeled by CFSE solution at $5 \mathrm{mM}$ of the final working concentration for $10 \mathrm{~min}$ at $37{ }^{\circ} \mathrm{C}$ in the dark. CFSE-labeled Teff cells were added to $5 \times$ volume of cold culture media and placed on ice for $5 \mathrm{~min}$ to stop the labeling process. Induced Treg cells were mixed with CFSE-labeled Teff cells at ratios of 1:1, 0.3:1, and 0:1 to produce a total cell count per well of $5 \times 10^{4} / 200 \mu \mathrm{l}$ RPMI 1640 media containing $1 \% \mathrm{P} / \mathrm{S}$ and $10 \%$ FBS in a 96-well plate. The mixed cells were incubated with vehicle or HDAC inhibitor $(0.01$ to $5 \mu \mathrm{M})$ in the presence of Dynabeads ${ }^{\circ}$ human T-activator $\mathrm{CD} 3 / \mathrm{C} 28$ (one bead to four cells) for 3 days in the dark in a humidified $5 \% \mathrm{CO}_{2}$ incubator. Proliferation of Teff cells was analyzed by CFSE dilution using LSR II flow cytometry (BD Bioscience). The results were analyzed with FlowJo software. The suppression ratio was calculated using the fold inhibition of cell proliferation by HDACi vs vehicle when the ratio of Treg:Teff $=1: 1$.

\section{Statistical analysis}

Statistical analysis was carried out with GraphPad Prism 5 (GraphPad Software Inc., San Diego, CA, USA). All data are expressed as mean \pm standard error of the mean (SEM). One-way analysis of variance (ANOVA) followed by Dunnett's multiple comparison tests and MannWhitney $U$ tests were used to compare differences between groups. A $p$ value $<0.05$ was considered statistically significant.

\section{Results}

We assessed the therapeutic effects of CKD-L on the severity of CIA in DBA1/J mice. After the onset of CIA, HDAC inhibitors were administered by subcutaneous injection. Arthritis progressed rapidly in the group treated with vehicle. CKD-L $(30 \mathrm{mg} / \mathrm{kg})$ significantly decreased the severity of arthritis compared with vehicle $(p<0.05)$, and Tubastatin A had a similar effect (Fig. 1a). The arthritis scores of the mice treated with $30 \mathrm{mg} / \mathrm{kg}$ CKD-L tended to be lower than those of the mice treated with $15 \mathrm{mg} / \mathrm{kg}$ CKD-L. Body weight was assessed every 2 days after the first drug administration. The body weights of the animals did not change significantly after administration of HDAC inhibitor (Fig. 1b). The changes in body weight between the first (day 21) and the last (day 38) assessment were not significantly different among the groups (Fig. 1c).

RA is characterized by synovial inflammation, bone erosion, cartilage damage, and leukocyte infiltration in the joints. To investigate the protective effects of CKD-L in the joints, the histological score was assessed in the 

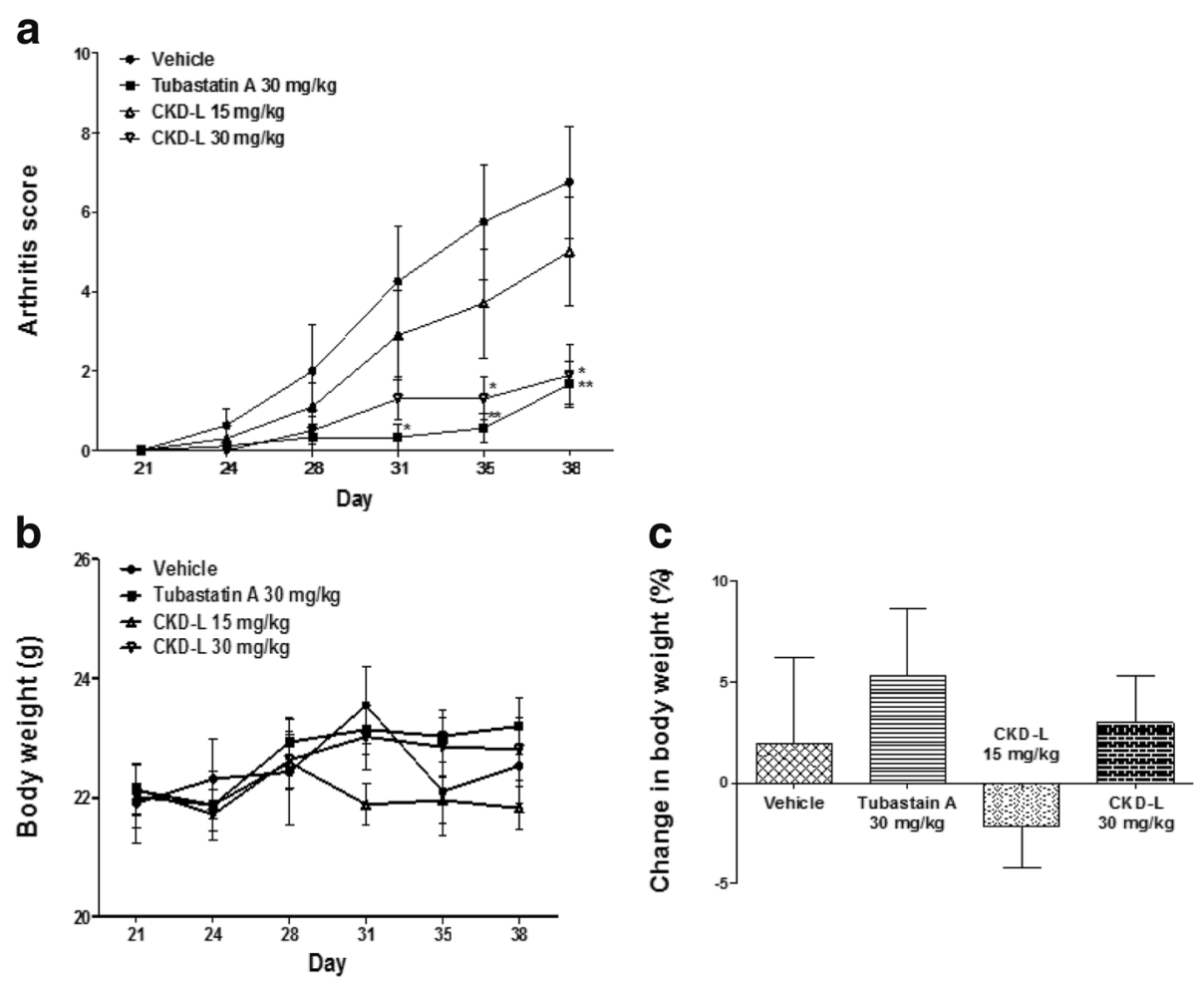

Fig. 1 Therapeutic effects of CKD-L on CIA mice. After the onset of arthritis, mice were treated with vehicle, Tubastatin A (30 mg/kg), or CKD-L ( 15 or $30 \mathrm{mg} / \mathrm{kg}$ ) subcutaneously every day for 18 days after the second immunization. CKD-L (30 mg/kg) and Tubastatin A significantly decreased arthritis score compared to vehicle (a). Body weight did not change during drug administration (b). The changes in body weight between day 21 and day 38 was not significantly different among the groups (c). ${ }^{*} p<0.05,{ }^{* *} p<0.01$, vs vehicle

knees and hind paws of mice by H\&E staining. Significantly more synovial inflammation, bone erosion, cartilage damage, and leukocyte infiltration were observed in the knee joints and hind paws of the mice treated with vehicle (arrows in Fig. 2) compared to Tubastatin A or CKD-L (Fig. 2a). CKD-L effectively inhibited arthritis. Synovial inflammation (Fig. 2b), bone erosion (Fig. 2c), cartilage damage (Fig. 2d), and leukocyte infiltration (Fig. 2e) were significantly decreased in the groups treated with CKD-L or Tubastatin A compared to the vehicle-treated group. The histological score was calculated by summation of four parameters: synovial inflammation, bone erosion, cartilage damage, and leukocyte infiltration (Fig. 2f). The histological score was significantly lower in mice treated with CKD-L $(p<0.001)$ or Tubastatin A $(p<0.001)$. These findings suggest that CKD-L may be significantly effective for the treatment of CIA. There was no significant difference in histological score between Tubastatin $\mathrm{A}$ and CKD-L.

Treg cells have an immunosuppressive role [29]. It was reported that the suppressive function of Treg cells in RA patients is defective [30, 34]. We assessed the effect of CKD-L on Treg cells during their induction. $\mathrm{CD} 4^{+} \mathrm{CD} 25^{-} \mathrm{T}$ cells were isolated from splenocytes of
C57BL/6 mice. $\mathrm{CD} 4^{+} \mathrm{CD} 25^{-} \mathrm{T}$ cells were incubated with vehicle or HDAC6 inhibitor (1 to $10 \mu \mathrm{M})$ in the presence of antiCD3/CD28 beads and recombinant TGF- $\beta 2$ in a 48-well plate for 6 days. CTLA-4 expression in $\mathrm{CD} 4^{+} \mathrm{CD} 25^{+}$Foxp $^{+}{ }^{+} \mathrm{T}$ cells was significantly increased after treatment with CKD-L $(p<0.001)$ or Tubastatin A $(p<0.05)$ compared to vehicle (Fig. 3).

Treg cells have an immunosuppressive role in immune tolerance [29]. It is known that the suppressive function of Treg cells from RA patients was defective in many studies [30,34]. We assessed the effect of CKD-L on the function of Treg cells. Treg cells $\left(\mathrm{CD} 4^{+} \mathrm{CD} 25^{+} \mathrm{T}\right.$ cells) and Teff cells $\left(\mathrm{CD} 4^{+} \mathrm{CD} 25^{-} \mathrm{T}\right.$ cells) were isolated from splenocytes of C57BL/6 mice. Treg cells were mixed with eFluor ${ }^{\circ} 670$-labeled Teff cells at ratios of 4:1 and $0: 1$. The mixed cells were incubated with vehicle or HDAC6 inhibitor (1 to $10 \mu \mathrm{M}$ ) in the present of antiCD3/CD28 beads for 4 days. Proliferation of Teff cells was inhibited after treatment with CKD-L and Tubastatin A in a dose-dependent manner compared to vehicle (Fig. 4a). As shown by suppression ratio (fold versus vehicle) at 1:4 ratio of Treg:Teff, the suppression ratio was increased 1.4 times by CKD-L treatment and 1.6 times by Tubastatin A treatment compared to vehicle treatment ( $p<0.001$, respectively) (Fig. 4b). 


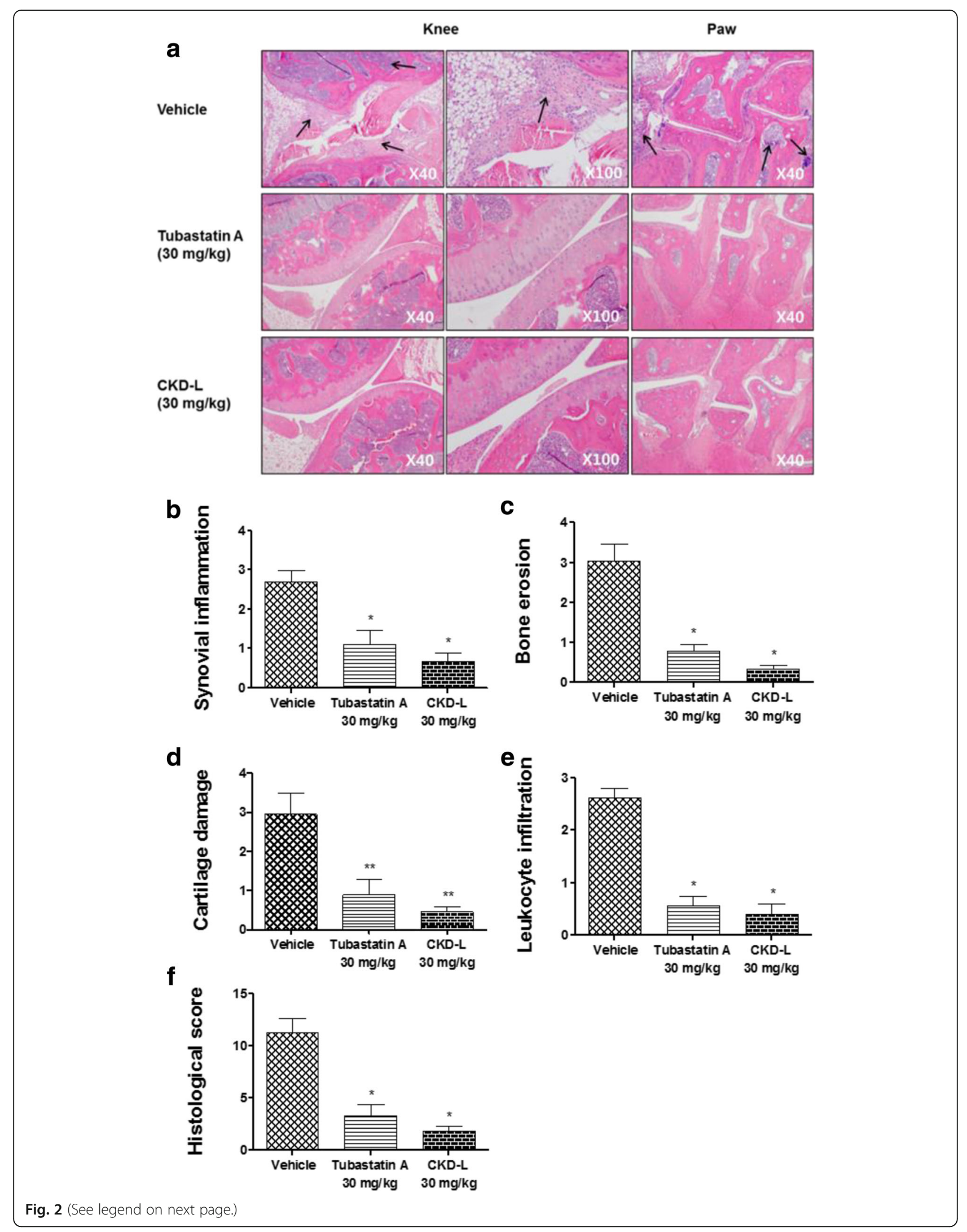


(See figure on previous page.)

Fig. 2 Histological analysis of CIA treated with CKD-L or Tubastatin A. Histological analyses were performed on knee joints $(\times 40, \times 100)$ and hind paws $(\times 40)$ stained by H\&E. Synovial inflammation, bone erosion, cartilage damage, and leukocyte infiltration were observed in the knee joints and hind paws of mice treated with vehicle (arrows) compared to Tubastatin A or CKD-L (a). The mean score of synovial inflammation (b), bone erosion (c), cartilage damage $(\mathbf{d})$, and leukocyte infiltration (e) were calculated using a scale of 0-4 (normal =0; mild = 1; moderate $=2$; marked = 3; severe $=4$ ), and these parameters significantly decreased after CKD-L or Tubastatin A treatment compared to vehicle treatment. Histological score was calculated by summation of these parameters (f). Histological score significantly decreased following treatment with CKD-L or Tubastatin A. ${ }^{*} p<0.001$, ${ }^{* *} p<0.01$, vs vehicle

To investigate the effect of CKD-L on PBMC of RA patients, cell viability was determined using the MTT assay. Cell viability was not affected by high concentrations of CKD-L or Tubastatin A (Fig. 5). However, ITF 2357 decreased cell viability at concentrations above $1 \mu \mathrm{M}$. The HDAC inhibitors were used in the experiments at concentrations that would not affect cell viability.

Isolated PBMC from RA patients were cultured with LPS $(100 \mathrm{ng} / \mathrm{ml})$ and HDAC inhibitors at different concentrations $(0.01$ to $5 \mu \mathrm{M})$ for $24 \mathrm{~h}$. The secretions of TNF, IL-10, and IL-1 $\beta$ in the cell culture supernatant were measured by multiplex immunoassay, and IL-6 secretion in the cell culture supernatant was measured by ELISA. CKD-L significantly inhibited TNF at concentrations of $0.01 \mu \mathrm{M}$ and $5 \mu \mathrm{M}$ (Fig. 6a). Also, CKD-L inhibited IL-1 $\beta$ at a concentration of $1 \mu \mathrm{M}$ (Fig. 6b) and increased IL-10 at a concentration of $5 \mu \mathrm{M}$ (Fig. 6d). ITF 2357 inhibited TNF at a concentration of $0.1 \mu \mathrm{M}$, and Tubastatin A inhibited TNF at concentrations of $1 \mu \mathrm{M}$ and $5 \mu \mathrm{M}$. ITF 2357 and Tubastatin A had no effect on IL-1 $\beta$ and IL-10. IL-6 production did not change following treatment with any HDAC inhibitor (Fig. 6c).

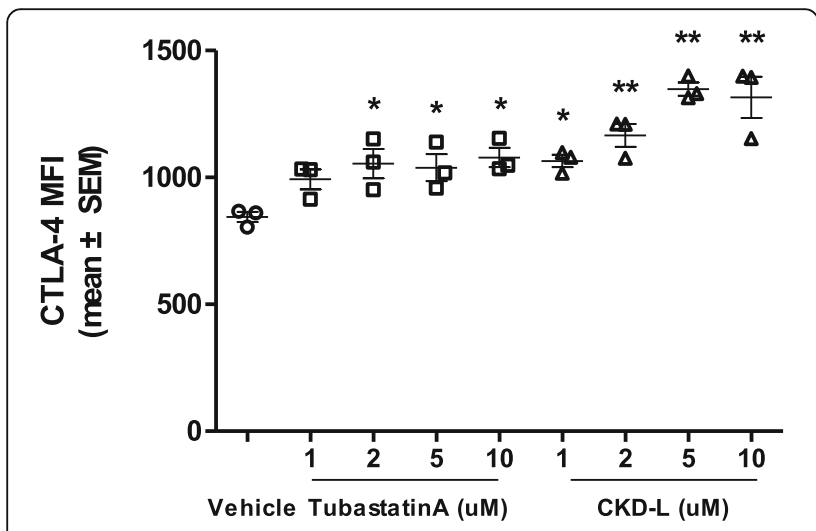

Fig. 3 Increased cytotoxic T-lymphocyte antigen-4 (CTLA-4) expression by CKD-L in Treg cells from C57BL/6 mice $(n=3)$. CD4 ${ }^{+} C D 25^{-}$T cells were isolated from splenocytes of $\mathrm{C} 57 \mathrm{BL} / 6$ mice. $\mathrm{CD} 4^{+} \mathrm{CD} 25^{-} \mathrm{T}$ cells were incubated with vehicle or HDAC6 inhibitors (1 to $10 \mu \mathrm{M})$ in the presence of antiCD3/CD28 beads and recombinant TGF- $\beta 2$ in a 48-well plate for 6 days. CTLA- 4 expression in $\mathrm{CD}^{+} \mathrm{CD} 25^{+} \mathrm{Foxp}^{+} \mathrm{T}$ cells was analyzed by mean fluorescence intensity (MFI; mean \pm SEM) using flow cytometry. ${ }^{*} p<0.05,{ }^{* *} p<0.001$, vs vehicle
Real-time PCR was conducted to measure the mRNA levels of TNF and IL-10. Total RNA was extracted from harvested cells and cDNA was synthesized by RT-PCR and then amplified. TNF mRNA expression was significantly decreased after treatment with a high concentration $(5 \mu \mathrm{M})$ of CKD-L $(p<0.001)$ (Fig. 7). ITF 2357 and Tubastatin A also decreased TNF mRNA expression $(p<0.001)$. However, IL-10 mRNA levels did not change after treatment with CKD-L.

THP-1 cells were activated with PMA for $24 \mathrm{~h}$ to induce macrophage differentiation. After differentiation, they were treated with vehicle or HDAC inhibitor $(0.1$ to $10 \mu \mathrm{M})$ for $24 \mathrm{~h}$ and then treated with $100 \mathrm{ng} / \mathrm{ml}$ LPS for $4 \mathrm{~h}$. TNF was significantly decreased after treatment with CKD-L in a dosedependent manner $(p<0.001)$ (Fig. 8). TNF secretion was also significantly inhibited by ITF $2357 \quad(p<$ $0.001)$ and Tubastatin A $(p<0.001)$.

Induced Treg cells derived from RA patients were mixed with CFSE-labeled Teff cells at ratios of 1:1, 0.3:1, and $0: 1$. The mixed cells were incubated with vehicle or HDAC inhibitor $(0.01$ to $5 \mu \mathrm{M})$ in the presence of Dynabeads $^{\ominus}$ human T-activator CD3/C28 (one bead to four cells) for 3 days. Proliferation of Teff cells was inhibited after treatment with CKD-L $(5 \mu \mathrm{M})$ and ITF 2357 $(0.1 \mu \mathrm{M})$ compared to vehicle (Fig. 9a). As the proportion of induced Treg cells was increased, proliferation of Teff cells was inhibited. In addition, in the Teff cell-only condition, ITF 2357 inhibited the proliferation of Teff cells but CKD-L did not have an effect. Therefore, the suppressive effect of CKD-L seems to be mediated by Treg cells. Tubastatin A had no suppressive effect in the suppression assay. The suppression ratio (fold versus vehicle) at 1:1 ratio of Treg:Teff was increased 1.5 times by CKD-L treatment and 1.8 times by ITF 2357 treatment compared to vehicle treatment $(p<0.05$ and $p<$ 0.01, respectively) (Fig. 9b).

\section{Discussion}

Epigenetic regulation potentially influences the pathogenesis of RA and can provide therapeutic targets for the treatment of RA [35]. HDAC inhibitors that modulate the activities of HDAC and HAT have been reported to have potential anti-inflammatory effects on RA in many studies $[5,22-25]$. In addition, 

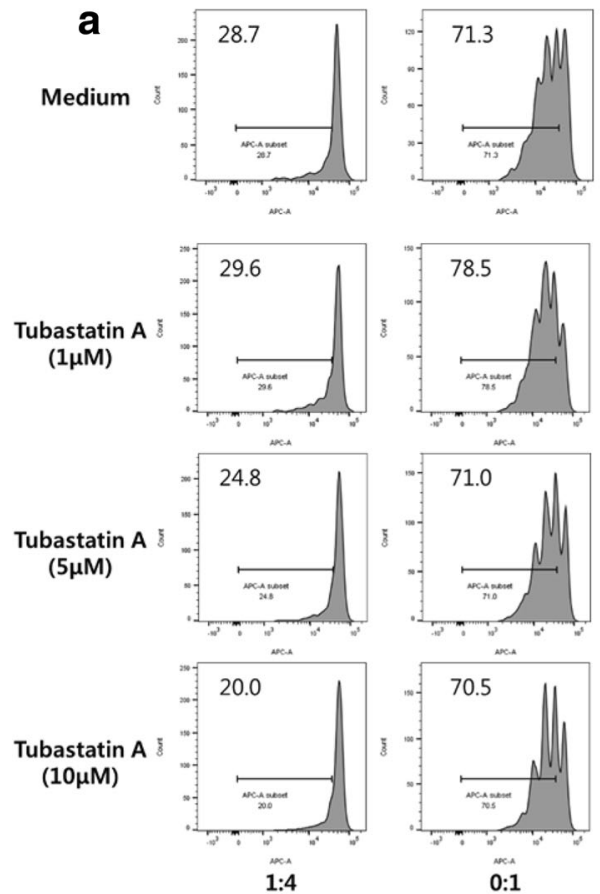

b

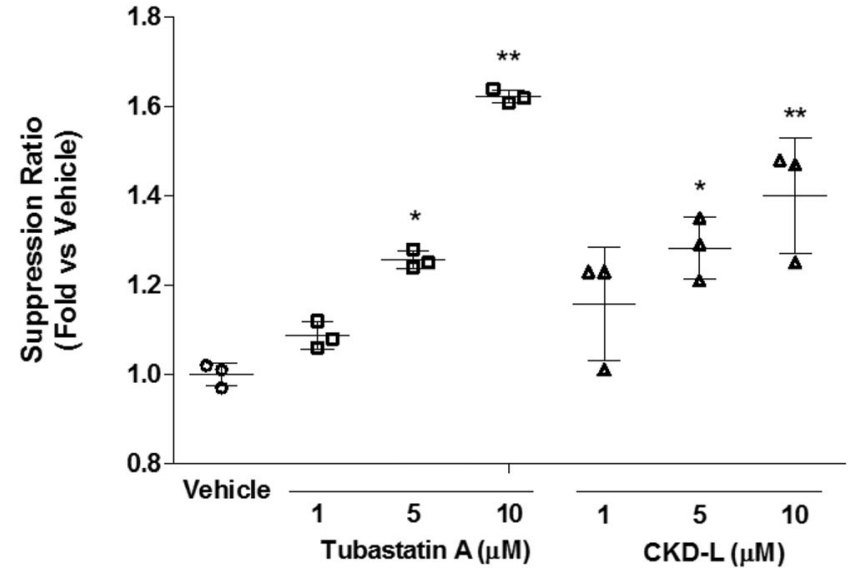

Fig. 4 Effect of CKD-L in the suppression assay using regulatory T (Treg) cells and effector T (Teff) cells from C57BL/6 mice $(n=3)$. Treg cells were mixed with efluor ${ }^{\otimes} 670$-labeled Teff cells at ratios of 4:1 and 0:1. The mixed cells were incubated with vehicle or HDAC6 inhibitor (1 to $\left.10 \mu \mathrm{M}\right)$ in the presence of antiCD3/CD28 beads for 4 days. a The proliferation of Teff cells was assessed by efluor ${ }^{\otimes} 670$ dilution using flow cytometry (representative data). $\mathbf{b}$ Suppression ratio (fold inhibition of cell proliferation by HDACi vs. vehicle) at a ratio of Treg:Teff $=1: 4 .{ }^{*} p<0.01$, ${ }^{* *} p<0.001$, vs vehicle

HDAC inhibitors ameliorated joint inflammation and bone destruction in animal experiments, including in the CIA model $[3,5,36]$. Therefore, in the present study, we hypothesized that CKD-L could have beneficial effects on CIA. We found that CKD-L significantly decreased both the arthritis score and the histological score by blocking CIA progression.

We assessed the effect of CKD-L on the function of Treg cells. Treg cells and Teff cells were isolated from splenocytes of C57BL/6 mice and cocultured. Proliferation of Teff cells was inhibited after treatment with CKD-L or Tubastatin A in a dose-dependent manner. The suppression ratio (fold inhibition of cell proliferation by HDACi vs vehicle) was approximately two times greater after CKD-L treatment compared to vehicle treatment (data not shown).

In RA, activated $\mathrm{CD} 4^{+} \mathrm{T}$ cells have an important role in initiating and perpetuating chronic inflammation [37]. 


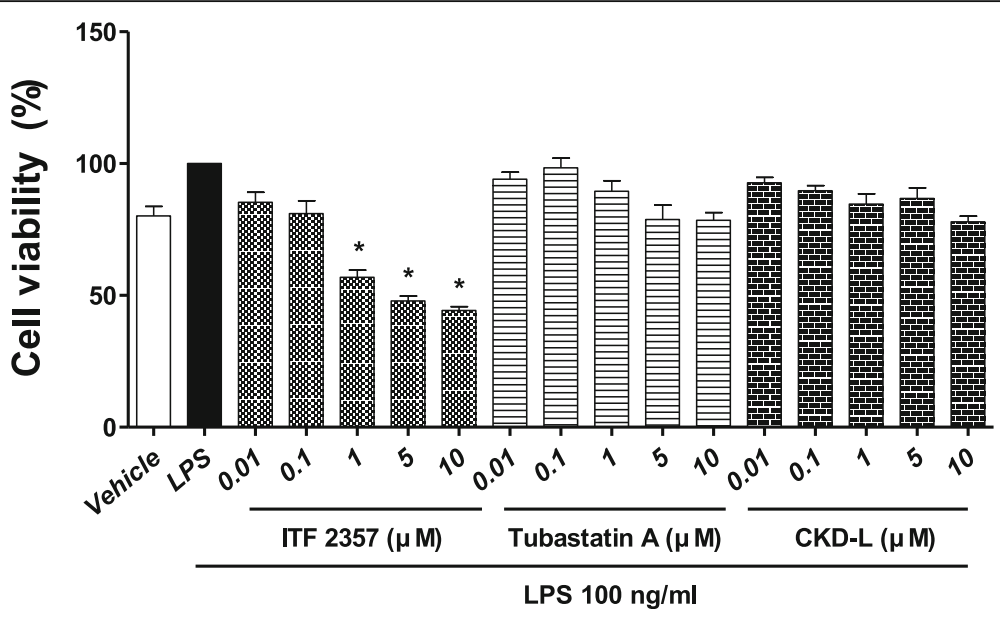

Fig. 5 Effects of CKD-L on cell viability in PBMC from RA patients $(n=6)$. PBMC from RA patients were cultured in a 96 -well plate for $24 \mathrm{~h}$ in the presence of lipopolysaccharide (LPS; $100 \mathrm{ng} / \mathrm{ml}$ ) and HDAC inhibitors at different concentrations ( 0.01 to $5 \mu \mathrm{M})$. Cell viability was determined using the MTT assay. Bars represent means and SDs. All experiments were carried out in triplicate. ${ }^{*} p<0.001$, vs LPS

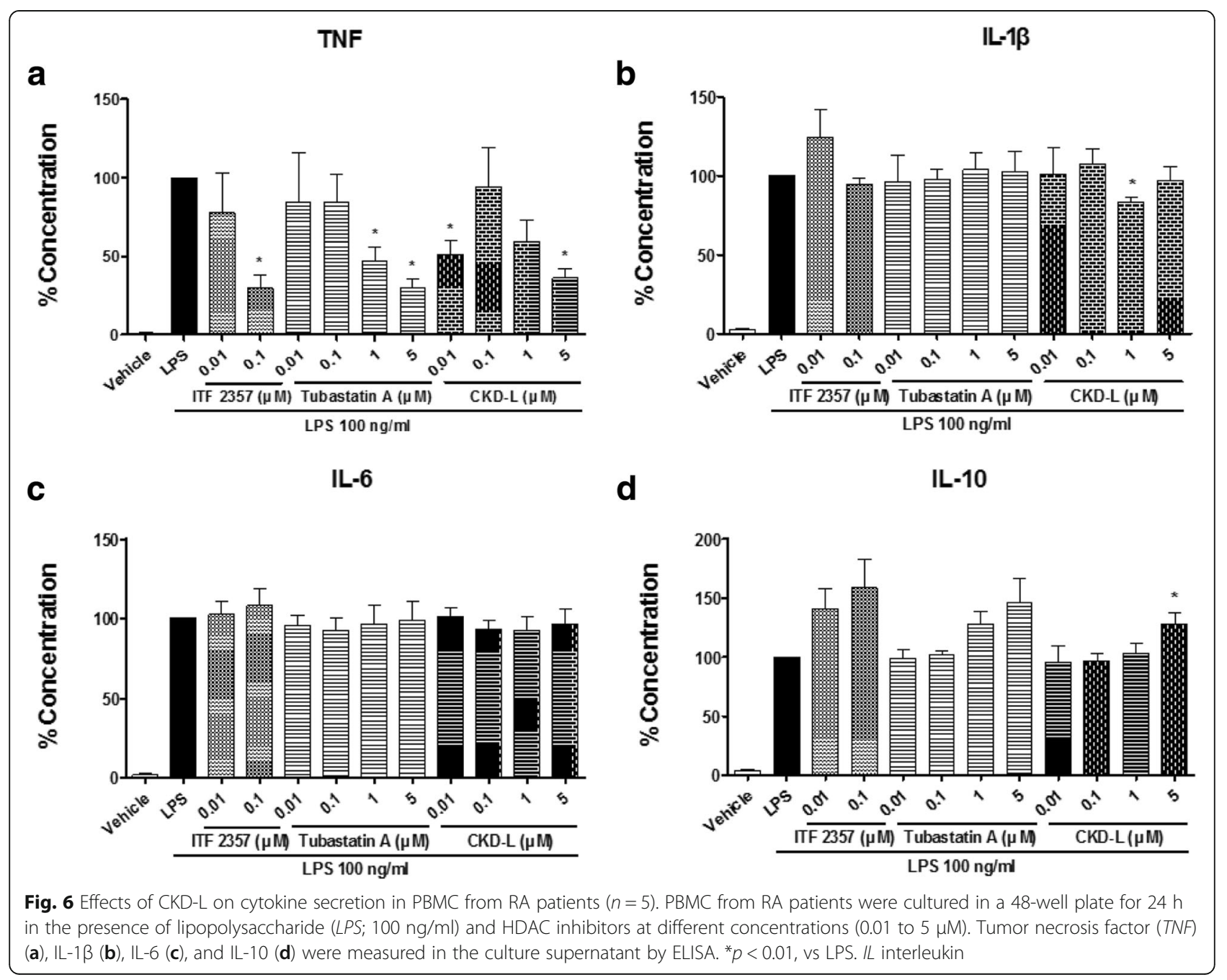




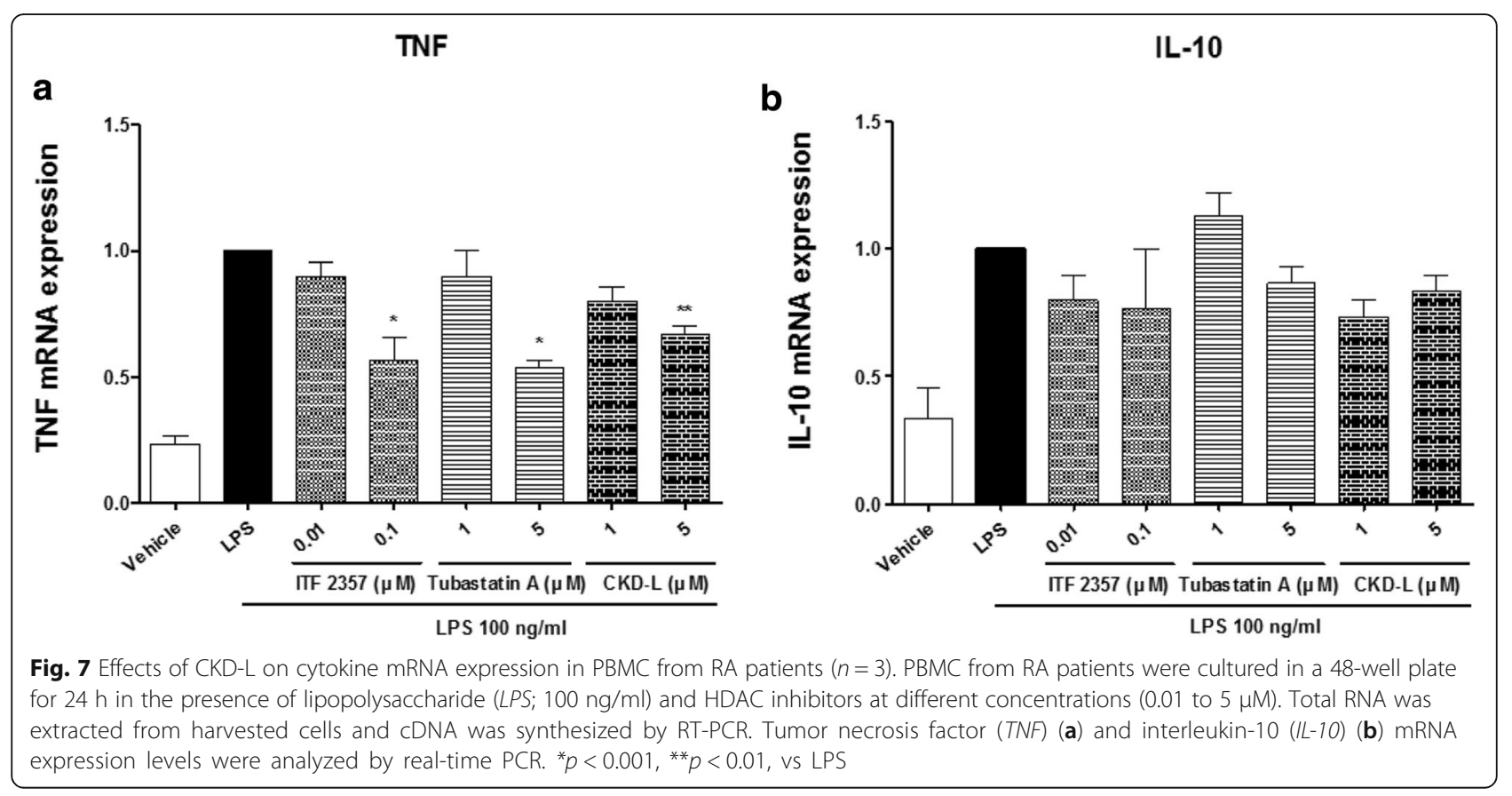

Based on their distinctive cytokine secretion profiles and functions, human $\mathrm{CD} 4^{+} \mathrm{T}$ cells can be divided into two major subtypes of cells, known as Th1 and Th2 cells. Th1 cells produce the proinflammatory cytokines IFN- $\gamma$, TNF, and IL-2, and promote macrophage activation, induce delayed-type hypersensitivity, and are involved in cell-mediated immunity. Th2 cells have been associated with downregulation of macrophage effector functions, they produce the anti-inflammatory cytokines IL-4, IL-5, IL-10, and IL-13, and mediate allergic immune responses [37-39]. IgG2a production is associated with a Th1 response, whereas IgG1 production is associated with a
Th2 response [40]. Therefore, we hypothesized that CKD-L can increase or maintain the level of IgG1 and decrease the level of IgG2a in serum from animals with CIA. We measured the levels of serum IgG1 and IgG2a by ELISA. However, the levels of serum IgG1 and IgG2a did not change significantly after CKD-L treatment (data not shown).

HDAC inhibitors have been reported to reduce the levels of TNF, IL- $1 \alpha$, IL- $1 \beta$, and IFN- $\gamma$ in LPS-stimulated normal PBMC and reduce the levels of proinflammatory cytokines such as TNF and IL-6 in PBMC of RA patients $[1,24,26,28]$. It was also reported that inhibition of

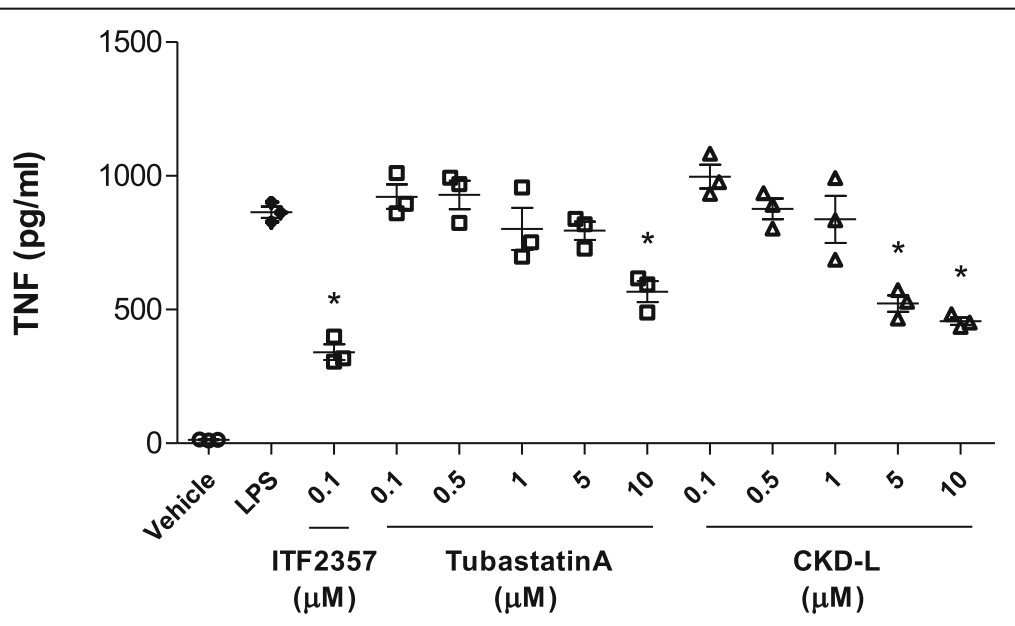

Fig. 8 Tumor necrosis factor (TNF) secretion in PMA-activated THP-1 cells $(n=3)$. THP-1 cells $\left(1 \times 10^{5}\right.$ cells/well) were cultured in a 24-well plate and activated with PMA $(10 \mathrm{ng} / \mathrm{ml})$ for $24 \mathrm{~h}$ to induce macrophage differentiation. PMA-activated THP-1 cells were treated with vehicle or HDAC inhibitors $(0.1$ to $10 \mu \mathrm{M})$ for $24 \mathrm{~h}$ and then treated with $100 \mathrm{ng} / \mathrm{ml}$ lipopolysaccharide (LPS) for $4 \mathrm{~h}$. The secretion of TNF was measured by ELISA. ${ }^{*} p<0.001$, vs LPS 
a

Vehicle
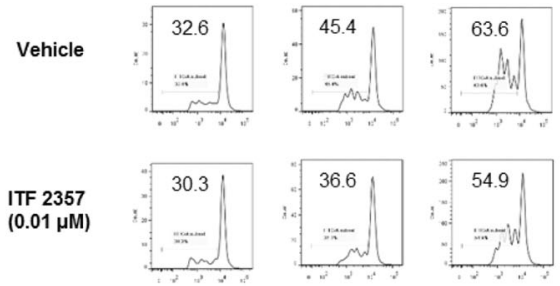

ITF 2357 $(0.1 \mu \mathrm{M})$
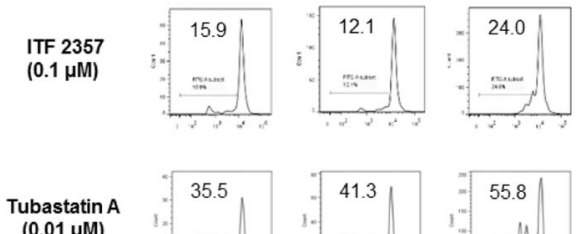

$(0.01 \mu \mathrm{M})$
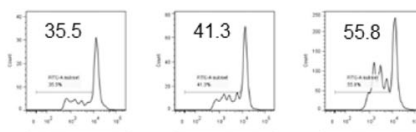

$\underset{(0.1 \mu \mathrm{M})}{\text { Tubastatin } \mathrm{A}}$
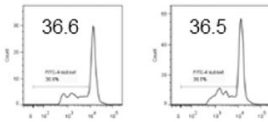

Tubastatin A $(1 \mu \mathrm{M})$
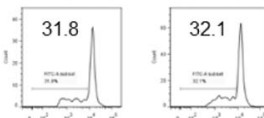

Tubastatin A $(5 \mu \mathrm{M})$

Treg : Teff ratio

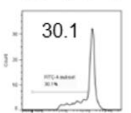

$1: 1$

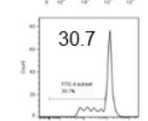

$0.3: 1$
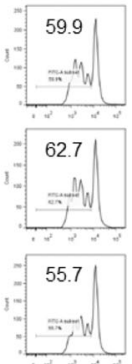

$0: 1$

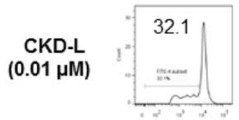

CKD-L
$(0.1 \mu \mathrm{M})$

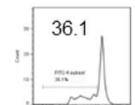

CKD-L (1 $\mu \mathrm{M})$
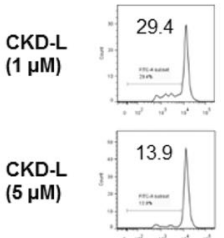

1:1
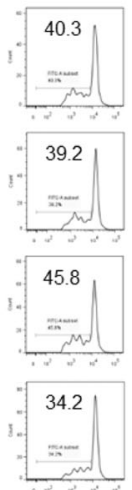

0.3:1
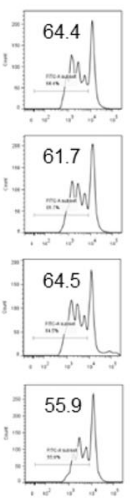

$0: 1$

b

Treg:Teff=1:1

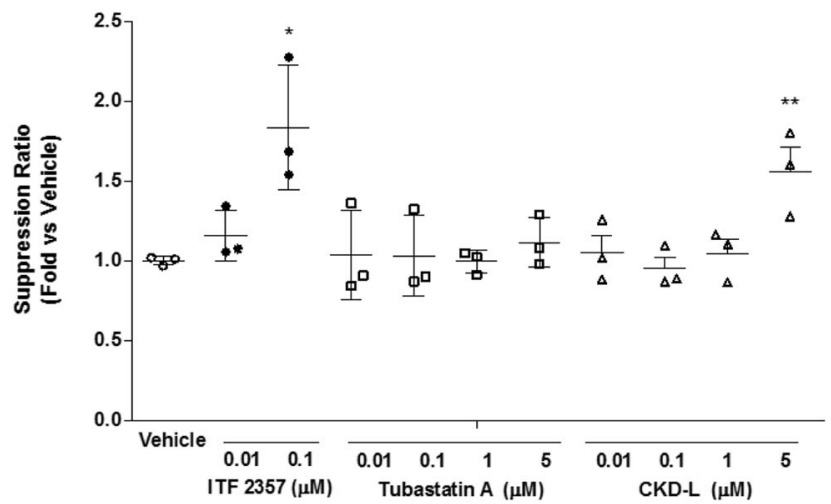

Fig. 9 Effects of CKD-L in the suppression assay using induced regulatory T (Treg) cells and effector T (Teff) cells from RA patients ( $n=3$ ). Treg cells induced from RA patients were mixed with carboxyfluorescein succinimidyl ester (CFSE)-labeled Teff cells at ratios of 1:1, 0.3:1, and 0:1. The mixed cells were incubated with vehicle or HDAC inhibitors (0.01 to $5 \mu \mathrm{M}$ ) in the presence of Dynabeads ${ }^{\circledR}$ human T-activator CD3/C28 (one bead to four cells) for 3 days. a The proliferation of Teff cells was assessed by CFSE dilution using flow cytometry (representative data). b Suppression ratio (fold inhibition of cell proliferation by HDACi vs vehicle) at the ratio of Treg:Teff $=1: 1 .{ }^{*} p<0.001,{ }^{* *} p<0.05$, vs vehicle

HDAC3 suppresses the inflammatory gene expression, including type I IFN production in RA FLS [41]. We found that CKD-L inhibited the secretion of TNF and IL- $1 \beta$, and increased the secretion of IL-10 in PBMC of RA patients treated with LPS and HDAC inhibitors. Also, as assessed by real-time PCR, CKD-L significantly inhibited TNF mRNA levels, in accordance with the results of measurements taken from the cell culture supernatant. Tubastatin A and ITF 2357 inhibited TNF secretion, but had no effect on IL-1 $\beta$ or IL-10. CKD-L, which regulates several cytokines such as TNF, IL-1 $\beta$, and IL-10, is expected to play an important role in abnormal immune responses in RA patients.

In RA, $\mathrm{T}$ cells and macrophages are major sources of proinflammatory cytokines and the activation, survival, and apoptosis of these cells may be regulated by HDAC 
and HAT [27]. It is known that HDAC inhibitors suppress TNF and IL- 6 production and transcription of cytokines in macrophages, and induce apoptosis in macrophages [28]. We found that CKD-L inhibited TNF secretion in PMA-activated THP-1 in a dose-dependent manner. Increased histone acetylation can regulate TNF production by controlling the access of transcription factors to promoter motifs directly or by regulating nucleosome remodeling.

Treg cells play an immunosuppressive role by producing TGF- $\beta$ or inhibiting Teff cells [29]. Treg cells from RA patients are defective in the suppression of proinflammatory cytokine production [30]. TNF in RA decreases the immunosuppressive effect by inducing the malfunction of Treg cells. It is known that inhibition of HDAC6 enhances the suppressive activity of Treg cells in inflammation and autoimmunity [12]. In the present study, in C57BL/6 mice, CKD-L increased CTLA-4 expression in $\mathrm{CD} 44^{+} \mathrm{CD} 25^{+} \mathrm{Foxp}^{+} \mathrm{T}$ cells more effectively than did Tubastatin A, and inhibited the proliferation of Teff cells on suppression assay. In the suppression assay on PBMC from RA patients, we found that CKD-L significantly inhibited the proliferation of Teff cells compared to vehicle. As the ratio of Treg cells increased, the proliferation of Teff cells was inhibited to a greater degree. Interestingly, ITF 2357 inhibited the proliferation of Teff cells when only Teff cells were present in culture. On the other hand, CKD-L had no effect when only Teff cells were present. Therefore, the suppressive effect of CKD-L seems to be regulated through Treg cells. Tubastatin A had no suppressive effect in the suppression assay. These results suggest that CKD-L promotes the suppressive function of Treg cells. HDAC inhibitors can increase acetylation of histone and Foxp3, leading to increased expression of Foxp3, and they increase the production and suppressive function of Treg cells [42]. Foxp3 proteins in Treg cells are present in a dynamic protein complex containing HAT and HDAC enzymes, and Foxp3 itself is acetylated on lysine residues. In addition, it has been reported that CTLA-4 expression is associated with acquisition of a suppressive function in activated human $\mathrm{CD} 4^{+} \mathrm{CD} 25^{-} \mathrm{T}$ cells [43].

There are few studies on the comparative effect of selective versus nonselective HDAC inhibitors. HDAC6 has been reported to modulate many important biological processes, including cell migration, immune responses, viral infections, and the degradation of misfolded proteins. These diverse functions of HDAC6 can be used as potential therapeutic targets in various diseases, such as systemic lupus erythematosus, cancer, and diabetes $[10,11]$. Our data demonstrated that CKD-L, a selective HDAC6 inhibitor, decreased the arthritis score and protected against joint destruction in the CIA model, and reduced the expressions of TNF and IL- $1 \beta$, and increased the expression of IL-10 in PBMC from RA patients. Also, CKD-L increased CTLA-4 expression and the suppressive function of Treg cells. Our data suggest that CKD-L may have a beneficial effect in the treatment of RA and further studies are needed to establish its role as a potential therapeutic agent.

\section{Conclusions}

CKD-L, a selective HDAC6 inhibitor, decreased the arthritis score in CIA, reduced the expression of TNF and $\mathrm{IL}-1 \beta$, and increased the expression of IL-10 in PBMC from RA patients. CKD-L increased CTLA- 4 expression and the suppressive function of Treg cells. These results suggest that CKD-L may have a beneficial effect in the treatment of rheumatoid arthritis.

\section{Abbreviations}

ACR: American College of Rheumatology; BSA: Bovine serum albumin; CD: Cluster of differentiation; CDNA: Complementary DNA; CFA: Complete Freund's adjuvant; CFSE: Carboxyfluorescein succinimidyl ester; CIA: Collagen-induced arthritis; CTLA: Cytotoxic T-lymphocyte antigen; DMARD: Disease-modifying antirheumatic drug; DMSO: Dimethyl sulfoxide; dNTP: Deoxynucleotide triphosphate; EDTA: Ethylenediaminetetraacetic acid; ELISA: Enzyme-linked immunosorbent assay; FBS: Fetal bovine serum; FLS: Fibroblast-like synoviocytes; Foxp3: Forkhead box P3; H\&E: Hematoxylin and eosin; HAT: Histone acetyltransferase; HDAC: Histone deacetylase; HSP: Heat shock protein; IFA: Incomplete Freund's adjuvant; IFN: Interferon; IL: Interleukin; LPS: Lipopolysaccharide; MACS: Magnetic cell sorting; MTT: Methylthiazol tetrazolium; MTX: Methotrexate; NAD: Nicotinamide adenine dinucleotide; NSAID: Nonsteroidal anti-inflammatory drug; P/S: Penicillin streptomycin; PBMC: Peripheral blood mononuclear cells; PBS: Phosphate-buffered saline; PMA: Phorbol 12-myristate 13-acetate; PRX: Peroxiredoxin; RA: Rheumatoid arthritis; RT: Room temperature; RT-PCR: Reverse-transcription polymerase chain reaction; Teff cell: Effector T cell; TGF: Transforming growth factor; TNF: Tumor necrosis factor; Treg cell: Regulatory T cell

\section{Acknowledgements}

The HDAC6 inhibitor CKD-L was kindly provided by CKD Pharm.

Funding

This study was supported by a grant from Chong Kun Dang Pharmaceutical Corporation (CKD Pharm), Korea.

\section{Availability of data and materials}

Not applicable.

\section{Authors' contributions}

$\mathrm{BRO}$ carried out the histological and immunological analyses in the CIA model, the cytokine assay, and the suppression assay in RA patients. Also, $\mathrm{BRO}$ drafted the manuscript. YWS conceived of the study and participated in its design and coordination, and helped to revise the manuscript. DHS, DB, $\mathrm{NH}$, and YIC carried out the animal experiments comprising the CIA model CTLA-4 expression, and the suppression assay. HJY, JKP, EYL and EBL participated in its design and coordination. All authors read and approved the final manuscript.

\section{Competing interests}

The authors declare that they have no competing interests.

\section{Consent for publication}

Not applicable.

\section{Ethics approval and consent to participate}

The human study was approved by the Institutional Review Board (IRB No. 1207-153-421) and informed consent was obtained from each patient. The animal study was reviewed and approved by the CKD Institutional Animal Care and Use Committee (approval number: S-16-038). 


\section{Publisher's Note}

Springer Nature remains neutral with regard to jurisdictional claims in published maps and institutional affiliations.

\section{Author details}

'Department of Molecular Medicine and Biopharmaceutical Sciences, BK 21 plus Graduate School of Convergence Science and Technology, College of Medicine, Seoul National University, Seoul, Korea. ${ }^{2}$ Department of Pharmacology and Toxicology, CKD Research Institute, CKD Pharmaceutical Company, Seoul, Korea. ${ }^{3}$ Division of Rheumatology, Department of Internal Medicine, Seoul National University College of Medicine, Seoul, Korea.

Received: 27 February 2017 Accepted: 1 June 2017

Published online: 03 July 2017

\section{References}

1. Gillespie J, Savic S, Wong C, Hempshall A, Inman M, Emery P, Grigg R, McDermott MF. Histone deacetylases are dysregulated in rheumatoid arthritis and a novel histone deacetylase 3-selective inhibitor reduces interleukin-6 production by peripheral blood mononuclear cells from rheumatoid arthritis patients. Arthritis Rheum. 2012;64(2):418-22.

2. Kim DH, Kim M, Kwon HJ. Histone deacetylase in carcinogenesis and its inhibitors as anti-cancer agents. J Biochem Mol Biol. 2003;36(1): 110-9.

3. Joosten LA, Leoni F, Meghji S, Mascagni P. Inhibition of HDAC activity by ITF2357 ameliorates joint inflammation and prevents cartilage and bone destruction in experimental arthritis. Mol Med. 2011;17(5-6):391-6.

4. Gregoretti IV, Lee YM, Goodson HV. Molecular evolution of the histone deacetylase family: functional implications of phylogenetic analysis. J Mol Biol. 2004:338(1):17-31.

5. Lin HS, Hu CY, Chan HY, Liew YY, Huang HP, Lepescheux L, Bastianelli E, Baron R, Rawadi G, Clement-Lacroix P. Anti-rheumatic activities of histone deacetylase (HDAC) inhibitors in vivo in collagen-induced arthritis in rodents. Br J Pharmacol. 2007;150(7):862-72.

6. New M, Olzscha H, La Thangue NB. HDAC inhibitor-based therapies: can we interpret the code? Mol Oncol. 2012;6(6):637-56.

7. Kong $Y$, Jung $M$, Wang $K$, Grindrod S, Velena A, Lee SA, Dakshanamurthy S, Yang Y, Miessau M, Zheng C, Dritschilo A, Brown ML. Histone deacetylase cytoplasmic trapping by a novel fluorescent HDAC inhibitor. Mol Cancer Ther. 2011;10(9):1591-9.

8. Lee JH, Mahendran A, Yao Y, Ngo L, Venta-Perez G, Choy ML, Kim N, Ham WS, Breslow R, Marks PA. Development of a histone deacetylase 6 inhibitor and its biological effects. Proc Natl Acad Sci U S A. 2013; 110(39):15704-9.

9. Li Y, Shin D, Kwon SH. Histone deacetylase 6 plays a role as a distinct regulator of diverse cellular processes. FEBS J. 2013;280(3):775-93.

10. Valenzuela-Fernandez A, Cabrero JR, Serrador JM, Sanchez-Madrid F. HDAC6: a key regulator of cytoskeleton, cell migration and cell-cell interactions. Trends Cell Biol. 2008;18(6):291-7.

11. Zhang $X$, Yuan Z, Zhang Y, Yong S, Salas-Burgos A, Koomen J, Olashaw N, Parsons JT, Yang XJ, Dent SR, Yao TP, Lane WS, Seto E. HDAC6 modulates cell motility by altering the acetylation level of cortactin. Mol Cell. 2007; 27(2):197-213.

12. de Zoeten EF, Wang L, Butler K, Beier UH, Akimova T, Sai H, Bradner JE, Mazitschek R, Kozikowski AP, Matthias P, Hancock WW. Histone deacetylase 6 and heat shock protein 90 control the functions of Foxp3(+) T-regulatory cells. Mol Cell Biol. 2011;31(10):2066-78.

13. Yamashita Y, Shimada M, Harimoto N, Rikimaru T, Shirabe K, Tanaka S, Sugimachi K. Histone deacetylase inhibitor trichostatin A induces cell-cycle arrest/apoptosis and hepatocyte differentiation in human hepatoma cells. Int J Cancer. 2003;103(5):572-6.

14. Marks PA, Richon VM, Rifkind RA. Histone deacetylase inhibitors: inducers of differentiation or apoptosis of transformed cells. J Natl Cancer Inst. 2000 92(15):1210-6.

15. Delcuve GP, Khan DH, Davie JR. Roles of histone deacetylases in epigenetic regulation: emerging paradigms from studies with inhibitors. Clin Epigenetics. 2012;4(1):5.

16. Bayarsaihan D. Epigenetic mechanisms in inflammation. J Dent Res. 2011; 90(1):9-17.
17. Han GM, O'Neil-Andersen NJ, Zurier RB, Lawrence DA. CD4 + CD25high $T$ cell numbers are enriched in the peripheral blood of patients with rheumatoid arthritis. Cell Immunol. 2008;253(1-2):92-101.

18. Gravallese EM. Bone destruction in arthritis. Ann Rheum Dis. 2002;61 Suppl 2:ii84-6.

19. Edwards CJ, Cooper C. Early environmental factors and rheumatoid arthritis. Clin Exp Immunol. 2006;143(1):1-5

20. Gaffo A, Saag KG, Curtis JR. Treatment of rheumatoid arthritis. Am J Health Syst Pharm. 2006;63(24):2451-65.

21. Feldmann M, Maini RN. Anti-TNF alpha therapy of rheumatoid arthritis: what have we learned? Annu Rev Immunol. 2001;19:163-96.

22. Blanchard F, Chipoy C. Histone deacetylase inhibitors: new drugs for the treatment of inflammatory diseases? Drug Discov Today. 2005;10(3): 197-204.

23. Mishra N, Brown DR, Olorenshaw IM, Kammer G. Trichostatin A reverses skewed expression of CD154, interleukin-10, and interferon-gamma gene and protein expression in lupus T cells. Proc Natl Acad Sci U S A. 2001;98(5): 2628-33.

24. Leoni F, Fossati G, Lewis EC, Lee JK, Porro G, Pagani P, Modena D, Moras ML, Pozzi P, Reznikov LL, Siegmund B, Fantuzzi G, Dinarello CA, Mascagni P. The histone deacetylase inhibitor ITF2357 reduces production of proinflammatory cytokines in vitro and systemic inflammation in vivo. Mol Med. 2005;11(1-12):1-15.

25. Chung YL, Lee MY, Wang AJ, Yao LF. A therapeutic strategy uses histone deacetylase inhibitors to modulate the expression of genes involved in the pathogenesis of rheumatoid arthritis. Mol Ther. 2003; 8(5):707-17

26. Grabiec AM, Korchynskyi O, Tak PP, Reedquist KA. Histone deacetylase inhibitors suppress rheumatoid arthritis fibroblast-like synoviocyte and macrophage IL-6 production by accelerating mRNA decay. Ann Rheum Dis. 2012;71(3):424-31

27. Lacy $P$, Stow JL. Cytokine release from innate immune cells: association with diverse membrane trafficking pathways. Blood. 2011; 118(1):9-18.

28. Grabiec AM, Krausz S, de Jager W, Burakowski T, Groot D, Sanders ME Prakken BJ, Maslinski W, Eldering E, Tak PP, Reedquist KA. Histone deacetylase inhibitors suppress inflammatory activation of rheumatoid arthritis patient synovial macrophages and tissue. J Immunol. 2010;184(5): 2718-28.

29. Esensten JH, Wofsy D, Bluestone JA. Regulatory T cells as therapeutic targets in rheumatoid arthritis. Nat Rev Rheumatol. 2009;5(10):560-5.

30. Nadkarni S, Mauri C, Ehrenstein MR. Anti-TNF-alpha therapy induces a distinct regulatory $T$ cell population in patients with rheumatoid arthritis via TGF-beta. J Exp Med. 2007:204(1):33-9.

31. Vishwakarma $S$, lyer $L R$, Muley M, Singh PK, Shastry A, Saxena A, Kulathingal J, Vijaykanth G, Raghul J, Rajesh N, Rathinasamy S, Kachhadia V, Kilambi N, Rajgopal S, Balasubramanian G, Narayanan S. Tubastatin, a selective histone deacetylase 6 inhibitor shows anti-inflammatory and anti-rheumatic effects. Int Immunopharmacol. 2013;16(1):72-8

32. Brand DD, Latham KA, Rosloniec EF. Collagen-induced arthritis. Nat Protoc 2007;2(5):1269-75.

33. Arnett FC, Edworthy SM, Bloch DA, McShane DJ, Fries JF, Cooper NS, Healey LA, Kaplan SR, Liang MH, Luthra HS, et al. The American Rheumatism Association 1987 revised criteria for the classification of rheumatoid arthritis. Arthritis Rheum. 1988:31(3):315-24.

34. Ehrenstein MR, Evans JG, Singh A, Moore S, Warnes G, Isenberg DA, Mauri C. Compromised function of regulatory T cells in rheumatoid arthritis and reversal by anti-TNFalpha therapy. J Exp Med. 2004;200(3):277-85.

35. Viatte S, Plant D, Raychaudhuri S. Genetics and epigenetics of rheumatoid arthritis. Nat Rev Rheumatol. 2013;9(3):141-53.

36. Lee J, Hong EC, Jeong H, Hwang JW, Kim H, Bae EK, Ahn JK, Choi YL, Han J, Cha HS, Koh EM. A novel histone deacetylase 6-selective inhibitor suppresses synovial inflammation and joint destruction in a collagen antibody-induced arthritis mouse model. Int J Rheum Dis. 2015:18(5):514-23.

37. Skapenko A, Wendler J, Lipsky PE, Kalden JR, Schulze-Koops H. Altered memory T cell differentiation in patients with early rheumatoid arthritis. J Immunol. 1999;163(1):491-9.

38. Del Prete GF, De Carli M, Ricci M, Romagnani S. Helper activity for immunoglobulin synthesis of T helper type 1 (Th1) and Th2 human T cell clones: the help of Th1 clones is limited by their cytolytic capacity. J Exp Med. 1991;174(4):809-13. 
39. Seder RA, Paul WE. Acquisition of lymphokine-producing phenotype by CD4 + T cells. Annu Rev Immunol. 1994;12:635-73.

40. Apparailly F, Verwaerde C, Jacquet C, Auriault C, Sany J, Jorgensen C. Adenovirus-mediated transfer of viral IL-10 gene inhibits murine collageninduced arthritis. J Immunol. 1998;160(11):5213-20.

41. Angiolilli C, Kabala PA, Grabiec AM, Van Baarsen IM, Ferguson BS, García S, Malvar Fernandez B, McKinsey TA, Tak PP, Fossati G, Mascagni P, Baeten DL, Reedquist KA. Histone deacetylase 3 regulates the inflammatory gene expression programme of rheumatoid arthritis fibroblast-like synoviocytes. Ann Rheum Dis. 2017;76(1):277-85.

42. Tao R, de Zoeten EF, Ozkaynak E, Chen C, Wang L, Porrett PM, Li B, Turka LA, Olson EN, Greene MI, Wells AD, Hancock WW. Deacetylase inhibition promotes the generation and function of regulatory T cells. Nat Med. 2007; 13(11):1299-307.

43. Zheng Y, Manzotti CN, Burke F, Dussably L, Qureshi O, Walker LS, Sansom DM. Acquisition of suppressive function by activated human CD4 + CD25$T$ cells is associated with the expression of CTLA-4 not FoxP3. J Immunol. 2008;181(3):16835213-91.

Submit your next manuscript to BioMed Central and we will help you at every step:

- We accept pre-submission inquiries

- Our selector tool helps you to find the most relevant journal

- We provide round the clock customer support

- Convenient online submission

- Thorough peer review

- Inclusion in PubMed and all major indexing services

- Maximum visibility for your research

Submit your manuscript at www.biomedcentral.com/submit
Biomed Central 